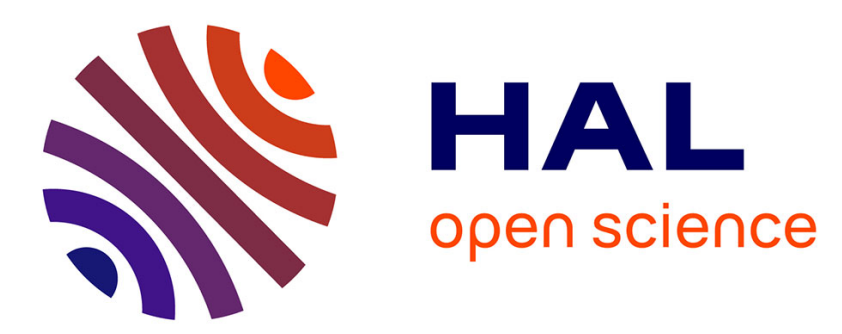

\title{
The impact of trophic changes over 45 years on the Eurasian perch, Perca fluviatilis, population of Lake Geneva
}

\author{
Jean-Paul Dubois, Christian Gillet, Nadine Hilgert, Gérard Balvay
}

\section{To cite this version:}

Jean-Paul Dubois, Christian Gillet, Nadine Hilgert, Gérard Balvay. The impact of trophic changes over 45 years on the Eurasian perch, Perca fluviatilis, population of Lake Geneva. Aquatic Living Resources, 2008, 21 (4), pp.401-410. 10.1051/alr:2008051 . hal-00857819

HAL Id: hal-00857819

https://hal.inria.fr/hal-00857819

Submitted on 30 May 2020

HAL is a multi-disciplinary open access archive for the deposit and dissemination of scientific research documents, whether they are published or not. The documents may come from teaching and research institutions in France or abroad, or from public or private research centers.
L'archive ouverte pluridisciplinaire HAL, est destinée au dépôt et à la diffusion de documents scientifiques de niveau recherche, publiés ou non, émanant des établissements d'enseignement et de recherche français ou étrangers, des laboratoires publics ou privés. 


\title{
The impact of trophic changes over $\mathbf{4 5}$ years on the Eurasian perch, Perca fluviatilis, population of Lake Geneva
}

\author{
Jean-Paul Dubois ${ }^{1, a}$, Christian Gillet ${ }^{1}$, Nadine Hilgert ${ }^{2}$ and Gérard Balvay ${ }^{1}$ \\ ${ }^{1}$ INRA, UMR CARRTEL, Centre Alpin de Recherche sur les Réseaux Trophiques des Ecosystèmes Limniques, 75 avenue de Corzent, \\ BP 511, 74203 Thonon-les-Bains Cedex, France \\ 2 UMR Analyse des Systèmes et Biométrie, ENSAM-INRA, 2 place Pierre Viala, 34060 Montpellier Cedex 1, France
}

Received 11 December 2007; Accepted 12 September 2008

\begin{abstract}
The change in catches and mean size of one-year-old perch (Perca fluviatilis) in Lake Geneva was studied between 1957 and 2005, and related to trophic changes and average temperature. The status of Lake Geneva, assessed on the basis of total phosphorus concentrations, switched from being oligotrophic before 1960 to eutrophic, with total phosphorus concentration reaching nearly $90 \mu \mathrm{g} \mathrm{L}^{-1}$ in 1976-1979. In response to management measures, the trophic status then returned to mesotrophy in the early 2000s. Zooplankton is the main food consumed by young perch, and quantities present (annual biovolumes of zooplankton) were recorded throughout the study period. The lake water temperature was also recorded. Data obtained from perch catches and perch spawns enabled eleven strong cohorts of perch to be identified. Strong cohorts dominated the stock for three years, until they were massively caught by fishermen. Yields have fluctuated widely, increasing rapidly until 1975, and subsequently decreasing, with an exceptional decline between 1976 and 1981. During the period 1977-1981, unfavourable climatic conditions in spring were probably the main cause of this fall in perch yields. For the other periods, perch yields and the mean size of one-year-old perch were significantly correlated with trophic parameters, total phosphorus concentration and zooplankton biovolume. Correlations are higher if only strong cohorts are taken into account. As a result of the re-oligotrophication process, perch growth has been progressively reduced, age at first maturity delayed and strong cohorts become less frequent; the mean size of $0+$ individuals in strong cohorts is significantly smaller than in the other cohorts, suggesting a population density effect in the context of a limited supply of zooplankton. During the study period, trophic changes in Lake Geneva have had more impact on perch growth and yield than has temperature, since no significant correlation could be detected between water temperature and perch growth.
\end{abstract}

Key words: Pre-Alpine lake / Fishing yields / Growth Eutrophication Phosphorus Zooplankton Perca fluviatilis

Résumé - Impact des changements trophiques sur les populations de perche, Perca fluviatilis, du lac Léman, durant 45 ans. Entre 1960 et 2005, l'évolution des captures totales et celle de la taille moyenne des perches (Perca fluviatilis) âgées d'un an du lac Léman ont été étudiées en relation avec l'évolution trophique et la température moyenne du milieu. Le statut trophique du lac, estimé à partir des concentrations en phosphore total, a évolué de l'oligotrophie avant 1960 jusqu'à l'eutrophie, le phosphore total atteignant près de $90 \mu \mathrm{g} \mathrm{L}^{-1}$ en 1976-1979. Suite aux mesures d'assainissement, le lac est redevenu mésotrophe dès 2001. Les quantités de zooplancton, principale nourriture des jeunes perches, ont été mesurées (biovolume annuel de zooplancton). La température a également été mesurée. En se basant sur les analyses faites sur les captures et sur les études menées lors de la reproduction, onze fortes cohortes de perches ont été identifiées. D’une manière générale, les fortes cohortes constituent l'essentiel du stock de perches pendant trois ans, jusqu'à ce que les pêcheurs les aient décimées. Les captures présentent d'importantes variations inter-annuelles; les quantités pêchées ont augmenté rapidement jusqu'en 1975 et diminuent depuis, avec une chute exceptionnelle entre 1976 et 1982. De 1977 à 1981, une succession de mauvaises conditions climatiques printanières explique probablement cette chute des captures. Pour les autres périodes, les quantités de perches capturées et la taille moyenne des perches à 1 an sont corrélées aux paramètres trophiques (concentration en phosphore total et biovolume de zooplancton). Les corrélations sont plus élevées si seules les fortes cohortes

\footnotetext{
a Corresponding author: dubois@thonon.inra.fr
} 
sont prises en compte. Avec le processus de ré-oligotrophisation, la croissance des perches diminue, l'âge de la maturité sexuelle est retardé et les fortes cohortes sont plus espacées; la taille moyenne des individus 0+ des fortes cohortes est significativement plus petite que celle des autres cohortes, traduisant un effet marqué de densité-dépendance vis-à-vis de la ressource limitée de zooplancton. Durant la période étudiée, les changements trophiques du lac Léman ont eu un effet plus marqué que la température sur la croissance et les captures de perches, puisque aucune corrélation positive n'a pu être mise en évidence entre la température de l'eau et la croissance ou les rendements de la pêche des perches.

\section{Introduction}

Lake Geneva, a pre-alpine lake in Western Europe, underwent eutrophication during the 1960s and 1970s. In the early 1980 s, a restoration program led to a reduction in phosphorus inputs, and resulted in a progressive reduction in the phosphorus concentration: a process known as re-oligotrophication. The yearly mean total phosphorus concentration (total $P$ ) in the lake water rose from $15 \mu \mathrm{g} \mathrm{L}^{-1}$ in 1960 to $89.5 \mu \mathrm{g} \mathrm{L}^{-1}$ in 1979 , and then fell to $29.4 \mu \mathrm{g} \mathrm{L}^{-1}$ in 2005 (data from the International Committee for the Protection of Lake Geneva: Commission Internationale pour la Protection des Eaux du lac Léman, CIPEL). The rise and fall in total $P$ have led to profound changes in the biocenosis and food web structures of the lake. Previous studies have described the response of phytoplankton assemblages (Anneville et al. 2002), and planktonic rotifer (Molinero et al. 2006), cladoceran, and copepod communities (Anneville et al. 2007). The effects of eutrophication and re-oligotrophication on fish populations in Lake Geneva have been studied mainly in salmonid species, Arctic charr (Salvelinus alpinus) (Champigneulle and Gerdeaux 1995) and whitefish (Coregonus lavaretus) (Gerdeaux 2004). Eurasian perch (Perca fluviatilis Linnaeus) have received less attention until now, despite the importance of this species for the fisheries of Lake Geneva, and the drop in landed catches recorded over several years (Gerdeaux et al. 2006).

Perch are found in lakes with a wide range of trophic conditions (Jeppesen 2000), and their recruitment seems little affected (Massol et al. 2007). Long-term surveys have revealed that changes in trophic levels and food resources can have a considerable impact on the growth and survival of perch populations. Perch have been seen to grow faster during eutrophication in many lakes, including Lake Erie (Nepzy 1977), Lake Constance (Hartmann 1975), and Lakes Hjalmaren and Malaren (Rundberg 1977). In Lake Constance, the increase in professional fishing catch during eutrophication was due to stronger year-classes, better growth rates and a reduction in cannibalism (Eckmann et al. 2006). Perch growth is also affected by fish density (Mehner et al. 1998; O'Gorman and Burnett 2001); perch in large populations usually grow slowly, and any reduction in their number results in improved individual growth, as observed in Lake Windermere (Le Cren 1958).

Lake re-oligotrophication is a recent phenomenon, and its effects on fish communities have been less amply documented than those of eutrophication (Gerdeaux et al. 2006). To date, the effects of re-oligotrophication on perch biology and population dynamics have only been described in Lake Constance (Eckmann et al. 2006). As a factor driving biological activity, water temperature can influence the growth of perch (Le Cren et al. 1977; Mehner et al. 1998; Paxton et al. 2004). However, one could ask what the relative importance of temperature is with regard to changes in the performance of perch populations subjected to major trophic changes. The present study investigates the effects of eutrophication and re-oligotrophication on changes in perch population: annual catches by fishermen, and the growth of $0+$ perch in Lake Geneva. Long-term series of data are available covering the periods of eutrophication and re-oligotrophication. These data include water physicochemistry, phytoplankton and zooplankton communities (data from CIPEL), and fish yields (data published each year by the relevant French and Swiss Government departments). We assessed the relative importance of changes in trophic factors (phosphorus and the amount of zooplankton, a main food source for young perch; Romare 2000), and temperature fluctuations on the changes in perch growth and yields.

\section{Materials and methods}

\subsection{Study site, phosphorus and zooplankton surveys, temperature recording}

Lake Geneva (46N, 6E), located on the border between France and Switzerland in Western Europe, is the largest lake in the pre-alpine region, with an area of $582 \mathrm{~km}^{2}$, and a volume of $89 \times 10^{9} \mathrm{~m}^{3}$. The quality of its water (nutrient concentrations, plankton quantity and composition) has been regularly analysed since 1959 by CIPEL: Data on physico-chemistry, productivity and the abundance of phyto- and zooplankton in the lake are determined in its central area, between Evian and Lausanne where the lake is deepest (309 m). CIPEL sampling campaigns are carried out every month; twice a month during the growing season (May to October), and once a month for the rest of the year (November to April). Values of the different parameters are then calculated on a yearly basis. Total phosphorus concentration (total $P$ ), expressed as the mean $P$ concentration $\left(\mu \mathrm{g} \mathrm{L}^{-1}\right)$ of the lake, is the mean value of all the $P$ measurements recorded at 20 different depths through the water column over the year (CIPEL protocol). Surface water temperature was continuously recorded from 1991 to 2005 by a probe connected to an automated weather station (type Enerco 411, Cimel Electronique, Paris, France). Prior to 1991, temperature was recorded by a mechanical temperature recorder (Jules Richard Instruments, Argenteuil, France). The annual sum of degree-days above $14{ }^{\circ} \mathrm{C}$ was also calculated. This parameter was shown to be positively correlated with perch recruitment in Lake Windermere (Le Cren et al. 1977).

A $200-\mu \mathrm{m}$ mesh size plankton net hauled vertically from $-50 \mathrm{~m}$ to the surface, thus taking in the trophogenic zone, was used to collect the zooplankton present. The plankton biovolume was then measured back at the laboratory in a decantation funnel; any algae present floated above the zooplankton, and were removed. The annual abundance, which is the cumulative 
amount of zooplankton, is expressed as the settled biovolume of zooplankton per unit area $\left(\mathrm{ml} \mathrm{m}^{-2}\right.$ year $\left.^{-1}\right)$ (CIPEL protocol).

\subsection{Fish study}

Since 1950, professional fishermen have reported the volume of their catches of commercial fish species to the authorities. Data are reported annually in France and Switzerland. Perch are caught with bottom nets, seines and traps. The minimum authorized mesh size is $23 \mathrm{~mm}$, and the minimum legal size above which perch can be landed is $150 \mathrm{~mm}$ TL (total length). Scientific samples were also taken with fishnets and traps of different mesh sizes, ranging from 10 to $30 \mathrm{~mm}$. Total length was measured to the nearest $\mathrm{mm}$ on fresh fish. Sex and maturity were recorded, and the age was determined from the opercular bones; fish size at one year was determined by back calculation (Le Cren 1947). The regression (r) between perch size and opercular radius was calculated from 3161 fish from Lake Geneva caught between 1966 and 2005.

$$
T L=15.0 X_{\mathrm{S}}+21.8
$$

$r^{2}=0.93$, with $58 \mathrm{~mm}<T L<373 \mathrm{~mm}$ and $3.5 \mathrm{~mm}<X_{\mathrm{S}}<$ $23.9 \mathrm{~mm}$

where $T L(\mathrm{~mm})$ is the length of fish when caught, and $X_{\mathrm{S}}$ is the opercular bone radius ( $\mathrm{mm}$ ) when caught. Samples were available for 31 different years. The length of one-year-old perch $\left(T L_{1}, \mathrm{~mm}\right)$ was estimated using the following equation:

$$
T L_{1}=T L\left(15.0 X_{\mathrm{S} 1}+21.8\right) /\left(15.0 X_{\mathrm{S}}+21.8\right)
$$

where $X_{\mathrm{S} 1}$ is the opercular radius $(\mathrm{mm})$ at the first annulus.

Of the fish analysed, 71 and 22 percent were $1+$ and $2+$, respectively. When $1+$ and $2+$ groups of perch of the same cohort were analysed, the differences observed between the calculated mean size at one year, and those calculated from each group never exceeded 5\%, except in 1992 (8\%).

\subsection{Identification of strong perch cohorts by studying the fluctuations of spawner populations}

Perch eggs are grouped in egg-strands or ribbons. Each female lays one egg-ribbon (Thorpe 1977), and this makes it possible to assess the number of mature females by counting the number of egg-ribbons. This is easier than trying to count the mobile adults (Lang 1987). The length and width of each eggribbon is correlated with the size of the corresponding mature female and histograms displaying the width of egg-ribbons can be used to assess the size structure and age of the breeding females (Lang 1987; Gillet et al. 1995; Dubois et al. 1996; Lang 1999). To make it easier to observe perch egg-ribbons, spawners can be attracted to artificial spawning substrates (Gillet and Dubois 1995). Artificial spawning substrates, consisting of conifer branches (spruce, Picea abies and yew, Taxus baccata), tied onto wire netting (length $2 \mathrm{~m}$, height $1 \mathrm{~m}$ ), were placed in Lake Geneva from 1984 to 2006 (Gillet and Dubois 2007). The spawning substrates were laid at three different depths: 4 ,

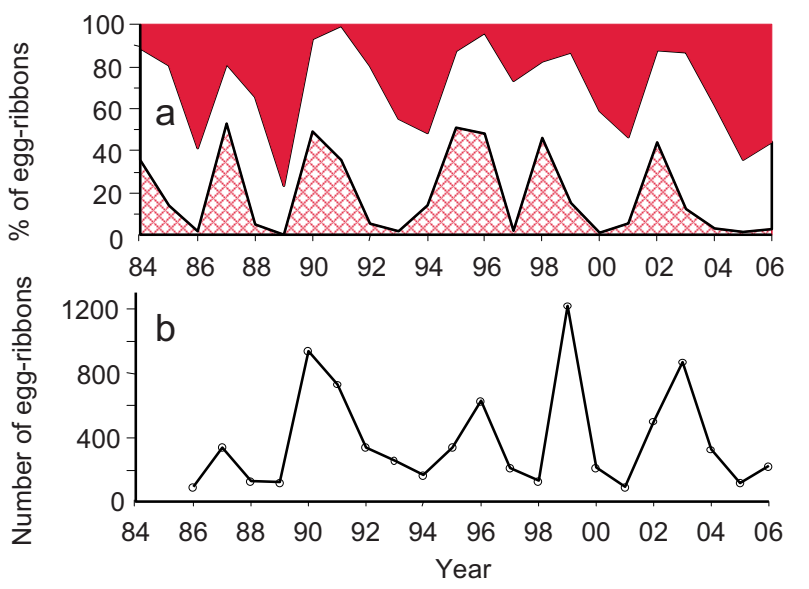

Fig. 1. Perch spawns (egg ribbons) collected on artificial substrates, from 1984 to 2006, in Lake Geneva. (a) Size distribution: hatched area: egg ribbon width up to $20 \mathrm{~mm}$, blank area: egg ribbon width $21-$ $40 \mathrm{~mm}$, dark area: egg ribbon width over $40 \mathrm{~mm}$; 150 and $210 \mathrm{~mm}$ perch correspond to 20 and $40 \mathrm{~mm}$ spawns, respectively. (b) Number of egg ribbons per spawning substrate.

8 and $12 \mathrm{~m}$. From 1984 to 1989 , several spawning substrates were laid at $4 \mathrm{~m}$ and $8 \mathrm{~m}$. From 1990, only one spawning substrate was laid at each of the three depths. Artificial spawning substrates were thus used to assess the size distribution and spawning intensity of mature females each year (number of egg-ribbons per spawning substrate). The yearly variations in the number of perch egg-ribbons can be related to the yearly fluctuations of perch yields, and to the mortality of perch populations (Lang 1987). It was possible to assess the birth year of strong perch cohorts in Lake Geneva by combining data on the number of egg-ribbons, the width distribution of egg-ribbons, and the age of females at their first spawning. A large number of egg-ribbons with the smallest width would therefore indicate that females belonging to a strong cohort had just reached maturity. This phenomenon was observed in 1984 (Lang 1987; Gillet et al. 1995; Lang 1999), as many 1+ perch reached their first maturity, and so it was deduced that a strong cohort had been born in 1982. In order to detect the occurrence of strong perch cohorts during the period of re-oligotrophication, observations of the egg-ribbons were carried on until 2006. According to Lang (1987), when a strong cohort perch reached the size for fishing, catches increased considerably, and the cohort was almost completely fished within three years. For example the strong cohort of 1982 produced an increase of perch yields in 1983, 1984 and 1985, with a peak value in 1984. Peak values in the perch yield time series also reflect the occurrence of strong cohorts in the fish stock.

The percentage of mature females of 2, 3 or 4 years were assessed from data of the Vaud county fisheries agency for the period 1982-1990, and from direct observations of fish caught by professional fishermen from 1991 to 2003.

\subsection{Statistical analyses}

Statistical analyses consisted mainly of identifying any significant links between variables, and in detecting changes in 
the progression of each time series. Means were compared using the Wilcoxon rank test. Pearson correlation coefficients, denoted as $r$, were calculated between total $P$, zooplankton biovolume, water temperature, perch yields and the size of one-year-old perch. Change was detected by a model selection method developed by Lavielle (2005), which has already been tested (e.g. Picard et al. 2005). This is a stochastic optimization procedure, known as Detection of Changes using Penalized Contrasts (DCPC), based on an adaptive choice of the penalty function for automatically estimating the number of change points. The time series are assumed to be piecewise stationary, i.e. that some of their characteristics change abruptly at some unknown instants. These changes can affect the probability distribution of the series. The number of changes is also unknown. In this case, change detection consists in estimating the timing and number of mean changes.

Most of the statistical analyses were performed using S-plus software (S-plus 2000). The DCPC procedure was carried out with the Matlab DCPC package, available at http://www.math.u-psud.fr/ lavielle/programs.

\section{Results}

\subsection{Determination of strong cohorts by studying the spawner population from 1984 to 2005 and the perch catches from 1960 to 2005}

The measurements of the width of perch egg-ribbons in the spawning areas from 1984 to 2005 revealed a succession of five peaks when small egg-ribbons (width up to $20 \mathrm{~mm}$ ) occurred (Fig. 1a). In 1984, small egg-ribbons accounted for a high percentage of spawns; they were laid by 2-year-old spawners belonging to the strong cohort of 1982 (Lang 1987; Gillet et al. 1995). Each peak of small egg-ribbons was followed by a peak of egg-ribbons of intermediate size (width in the $21-40 \mathrm{~mm}$ range), which in turn was followed by a peak of large egg-ribbons (width over $40 \mathrm{~mm}$ ). Five peaks were also observed in the number of egg-ribbons per spawning substrate (Fig. 1b). The first two peaks were synchronous with the small egg ribbon peaks, and each of the last three peaks appeared one year later.

The age when female perch matured in Lake Geneva had progressively increased from $1+$ to $2+$ during the reoligotrophication period (Table 1). The peak of small eggribbons observed in 1987 had been spawned by a strong cohort born in 1985 (according to Table 1, Fig. 1). From 1988, most of the females were mature at $2+$ and, by deduction, the small egg-ribbon peaks observed in 1995 and 1996, preceded by a slight increase in 1994, were spawned by two strong cohorts born in 1992 and 1993 respectively. At the end of study series, the peak of small egg-ribbons observed in 2002 was spawned by a strong cohort born in 1999. Strong perch cohorts were born in 1982, 1985, 1988, 1992, 1993 and 1999. The highest peak of egg-ribbon per spawning substrate was observed in 1999. It was preceded by a peak of small egg-ribbons in 1998. The 1999 peak probably corresponded to the spawning of 3year-old females, born in 1996; Lang (1999) observed that a strong perch cohort was born in 1996. Four peaks of catches occurred between 1960 and 1976, corresponding to four strong

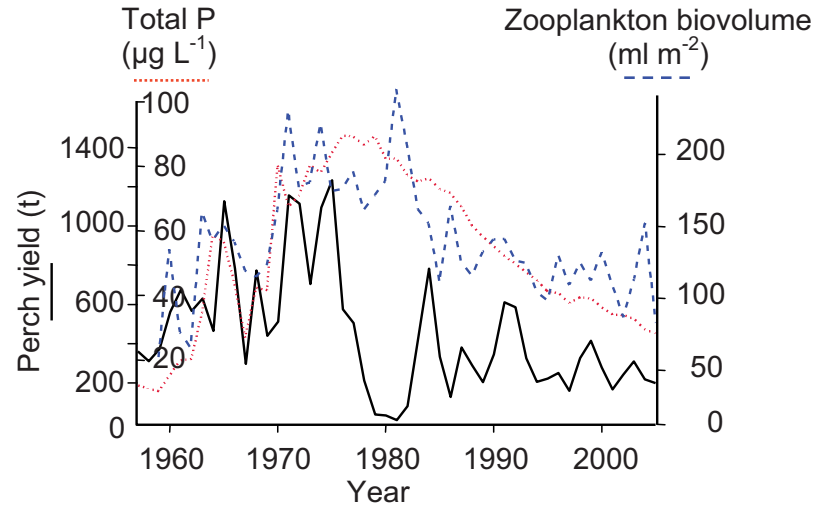

Fig. 2. Trends in total phosphorus concentration (total $P$, in $\mu \mathrm{g} \mathrm{L}^{-1}$ ), annual biovolume of settled zooplankton $\left(\mathrm{ml} \mathrm{m}^{-2}\right)$ and perch yield $(t)$ in Lake Geneva.

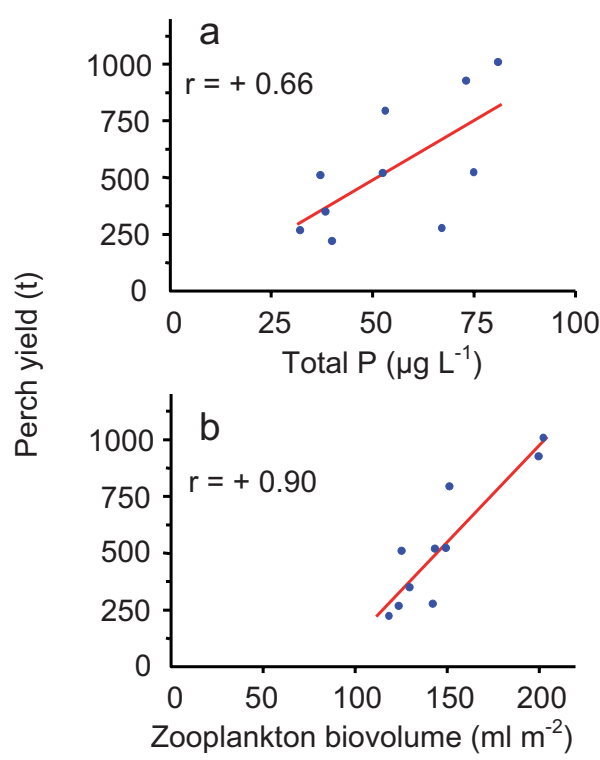

Fig. 3. (a) Correlations between total $P$ and perch yields; and (b) between zooplankton biovolume and perch yields. Data correspond to the means of 3 years of fishing of strong cohorts.

cohorts that appeared in 1963, 1966, 1970 and 1973 respectively (Fig. 2). Over the whole observation period, peak values occurred at three- or four-year intervals, except between 1976 and 1983. From 1977 to 1981, unusually cold growing seasons occurred that were characterized by sums of degree-days above $14{ }^{\circ} \mathrm{C}$ of less than 500 (range 427-494). Years of birth of strong cohorts corresponded to higher sums of degree-days: 676 in 1982, 624 in 1985, 688 in 1988.

\subsection{Changes in perch yields during the eutrophication and re-oligotrophication of Lake Geneva; effect of climate changes}

During the period of eutrophication (1957-1979), perch yields increased from 1957 to 1975 , and decreased sharply thereafter. The decrease continued up to 1981, when the period of re-oligotrophication began. Perch yields then first rose from 
Table 1. Change in the $\%$ of sexually mature female perch in Lake Geneva and total phosphorus concentration. The numbers of fishes analysed are given in brackets.

\begin{tabular}{|c|c|c|c|c|}
\hline \multirow[t]{2}{*}{ Period } & \multicolumn{3}{|c|}{ Age of fish at spawning } & \multirow[t]{2}{*}{ Total $P\left(\mu \mathrm{g} \mathrm{L}^{-1}\right)$} \\
\hline & $1+$ & $2+$ & $3+$ & \\
\hline 1969-1971 (*) & $58(?)$ & $73(?)$ & $100(?)$ & $45-70$ \\
\hline $1979-1983(*)$ & $84(232)$ & $100(16)$ & & $75-90$ \\
\hline $1988-1990(*)$ & $40(135)$ & $<100(148)$ & & $53-62$ \\
\hline 1991-1995 (present study) & $43(130)$ & $77(150)$ & $>90(71)$ & $42-52$ \\
\hline 1996-2003 (present study) & $4(45)$ & $61(150)$ & $100(33)$ & $32-40$ \\
\hline
\end{tabular}

(*) Swiss Fisheries Agency.

1981 to 1984 , but subsequently fluctuated widely (Fig. 2). During the whole study period, no significant correlation could be detected between total $P$ level and perch yield $(r=+0.14$, $d f=47, p>0.05)$. The correlation was however significant if the years from 1976 to 1983, corresponding to a sharp decrease of perch yields, were excluded from the calculation $(r=+0.44, d f=39, p<0.01)$. The coefficient of correlation was even higher if only catches corresponding to the strong cohorts were taken into account, i.e. the sums of perch yields during the peak periods (sum of catches during a peak value year, the year preceding it, and the one following it) $(r=+0.66$, $d f=8, p<0.05$, Fig. 3). Only one change in the mean perch yield has been detected by the DCPC procedure since 1957 ( $p=0.008$ ). This change was estimated to have occurred between 1977 and 1978 (Fig. 4a), when the trophic level of Lake Geneva was at its highest. Mean perch yield was about $683 \pm 64 \mathrm{t}\left(11.7 \pm 1.1 \mathrm{~kg} \mathrm{ha}^{-1}\right)$ before 1977, and $289 \pm 32 \mathrm{t}$ $\left(5.0 \pm 0.5 \mathrm{~kg} \mathrm{ha}^{-1}\right)$ afterwards $(p<0.001$, Wilcoxon rank test, $n=49)$.

From 1959 to 2005, the overall zooplankton biovolume was positively correlated with the total $P$ level $(r=+0.75$, $d f=45, p<0.001)$. After 1983 however, during reoligotrophication, despite inter-annual fluctuations, it never exhibited any consistent upward or downward trend ( $p>0.05$, Mann-Kendall test). Using the DCPC procedure, two changes are thought to have occurred in the time series of zooplankton biovolume: between 1969 and 1970, and between 1983 and 1984 ( $p<0.001$ ) (Fig. 4a). The yearly mean was high from 1970 to $1983\left(198 \pm 8 \mathrm{ml} \mathrm{m}^{-2}\right)$. From 1984 to 2005, the yearly mean was fairly similar to that calculated before $1969\left(129 \pm 5\right.$ and $123 \pm 11 \mathrm{ml} \mathrm{m}^{-2}$ respectively) and was significantly lower than from 1970 to 1983 , when the trophic level of Lake Geneva was at its highest, based on the concentration of total $P$ (Wilcoxon rank test, $n=47, p<0.001$ ). The coefficient of multiple determination between zooplankton biovolume and total $P$ in combination with water temperature and perch yield was not very different from the coefficient of determination between zooplankton biovolume and total $P$ alone: 0.60 vs. 0.57 . No significant correlation could be detected between zooplankton biovolume and perch yield since $1959(r=+0.25, d f=45, p>0.05)$. However the correlation was significant if the years from 1976 to 1983 were excluded $(r=+0.60, d f=37, p<0.001)$, and was even more marked if only the strong cohorts were taken into account $(r=+0.90, d f=8, p<0.001)$ (Fig. 3). The coefficient of multiple determination between perch yield and zooplankton biovolume in combination with total $P$ and water temperature
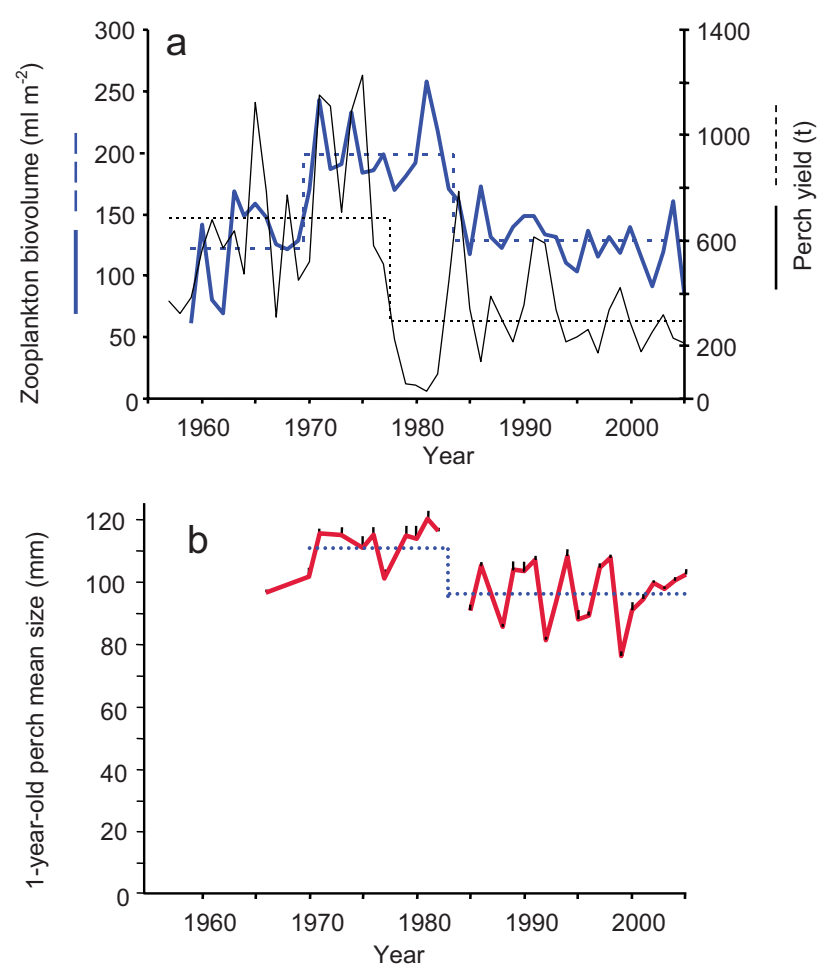

Fig. 4. (a) Trends in perch yield ( $t$ ) (fine unbroken line) and zooplankton biovolume $\left(\mathrm{ml} \mathrm{m}^{-2}\right.$ year $^{-1}$ ) (bold unbroken line); and (b) mean size (with standard error) of one-year-old perch in Lake Geneva (unbroken lines). Mean levels and changes detected by the DCPC procedure are indicated by dotted lines.

was not very different from the coefficient of determination between perch yield and zooplankton biovolume alone: 0.40 vs. 0.36 .

Yearly means of surface water temperature fluctuated widely. Several consecutive warm years were often preceded and followed by several cold years. Using the DCPC procedure, one change is thought to have occurred in the time series of surface water temperature from 1957: this change was estimated to have occurred between 1987 and 1988. The temperature mean was $11.8 . \pm 0.1{ }^{\circ} \mathrm{C}$ before 1988 , and $12.5 \pm$ $0.1{ }^{\circ} \mathrm{C}$ afterwards $(p<0.001$, Wilcoxon Rank Test, $n=51$ Fig. 5). During the whole study period, surface temperature was negatively correlated with total perch yield, zooplankton biovolume and total $P$ (Table 2, Fig. 5). 
Table 2. Coefficients of correlation $r^{2}$ between the different parameters; in the correlations with perch yield, data from the period 1976-1983 have been excluded. *: $p<0.05, * *: p<0.01, * * *: p<0.001$.

\begin{tabular}{llllll}
\hline & Phosphorus & Zooplankton & Temperature & Perch yield & Perch size \\
\hline Phosphorus & 1 & & & & \\
Zooplankton & $0.57^{* * *}$ & 1 & & & \\
Temperature & $0.09^{*}$ & $0.10^{*}$ & 1 & & \\
Perch yield & $0.19^{* *}$ & $0.36^{* * *}$ & $0.13^{*}$ & 1 & \\
Perch size & $0.29^{*}$ & $0.46^{* * *}$ & 0.04 & 0.003 & 1 \\
\hline
\end{tabular}

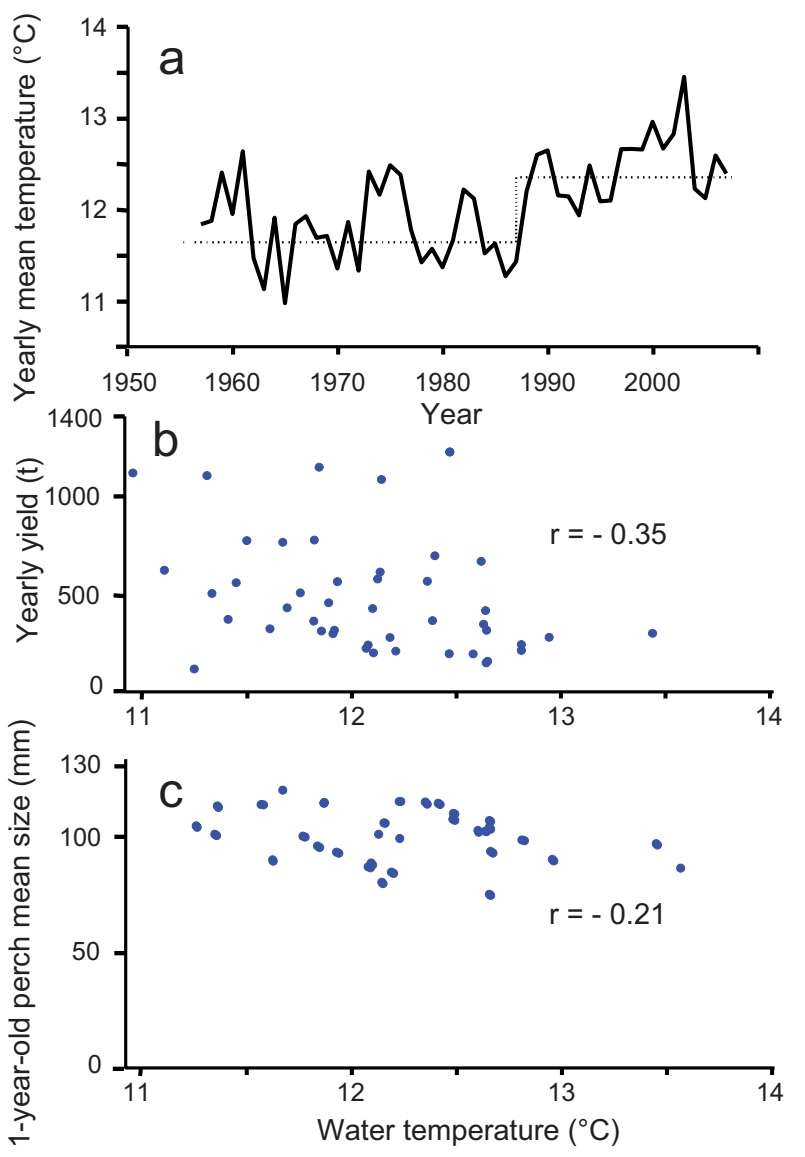

Fig. 5. Annual mean temperature $\left({ }^{\circ} \mathrm{C}\right)$ of the surface water of Lake Geneva. (a) Temperature trend (unbroken line) with mean levels and change detected by the DCPC procedure (dotted line). (b) Correlations between temperature and annual perch yield $(t)$; and (c) temperature and mean size ( $T L \mathrm{~mm}$ ) of one-year-old perch.

\subsection{Comparison of juvenile perch growth during eutrophication and re-oligotrophication; influence of water temperature}

The size of perch juveniles at the end of their first growing season was significantly higher during the period of high trophic level (1971-1982: yearly mean $T L: 113 \pm 2 \mathrm{~mm}$ ), when total $P$ level and zooplankton biovolume were at their highest values, than it was from 1985 to 2005, and before 1970 (yearly mean TL: $97 \pm 2 \mathrm{~mm}$ ), when total $P$ was below $75 \mu \mathrm{g} \mathrm{L}^{-1}$ and zooplankton biovolume below $150 \mathrm{ml} \mathrm{m}^{-2}$ (Wilcoxon rank test, $n=31, p<0.001)$. A change in the mean size of oneyear-old perch, calculated by the DCPC procedure $(p<0.001)$
(Fig. 4b), occurred between 1982 and 1985. It is not possible to be more precise about exactly when this change occurred, because perch born in 1983 and 1984 were very scarce and samples insufficient to estimate their mean size. Over the whole study period, the mean size of $0+$ perch was significantly related to the total $P$ level $(r=+0.54, d f=29$, $p<0.001)$, and to the zooplankton biovolume $(r=+0.67$, $d f=29, p<0.001)$. The correlations are higher if only strong cohorts are taken into account (mean size and zooplankton: $r=+0.92, d f=8, p<0.001$, mean size and total $P$ : $r=+0.72, d f=8, p<0.05$, Fig. 6). During the period of re-oligotrophication, from 1985 to 2005 , the mean $0+$ size of strong cohorts (as defined in the previous paragraph: 1985, 1988, 1992, 1993, 1996 and 1999) was significantly smaller than that of the other cohorts born in other years during the same period (Wilcoxon rank test, $n=19, p<0.001$ ). No significant correlation could be detected between lake water temperature and perch size (Table 2, Fig. 5). The coefficient of multiple determination between perch size and zooplankton biovolume in combination with total $P$ and water temperature was not very different from the coefficient of determination between perch size and zooplankton biovolume alone: 0.49 vs. 0.46 .

\section{Discussion}

\subsection{Succession of strong and weak cohorts}

Strong cohorts of perch were generally separated by intervals of three or four years, as has also been reported for perch catches in Lake Geneva during the periods 1963-1976 and 1983-1986 (Lang and Büttiker 1985; Lang 1987), and spawner populations during the 1984-1993 period (Gillet et al. 1995). Wide interannual fluctuations in the strength of the year classes have been reported for Lake Windermere (Craig et al. 1979), in Crystal Lake for yellow perch (P. flavescens) (Sanderson et al. 1999), in Lake Abborrtjarn (Persson et al. 2000), in Lake Neuchâtel from 1961 to 1977 (data of the Neuchâtel county fisheries agency), and in Lake Constance (Eckmann et al. 2006). Predation exerted by perch on the following year-class (cannibalism) is an important cause of inter-annual fluctuations (Thorpe 1977). Persson et al. (2000) showed that the emergence and development of a new yearclass can only occur in years when the older year-class perch have been strongly reduced. In the oligotrophic Crystal Lake, $0+$ yellow perch were eliminated for four successive years as a result of competition and cannibalism by older perch (Sanderson et al. 1999); three dominant cohorts were observed 


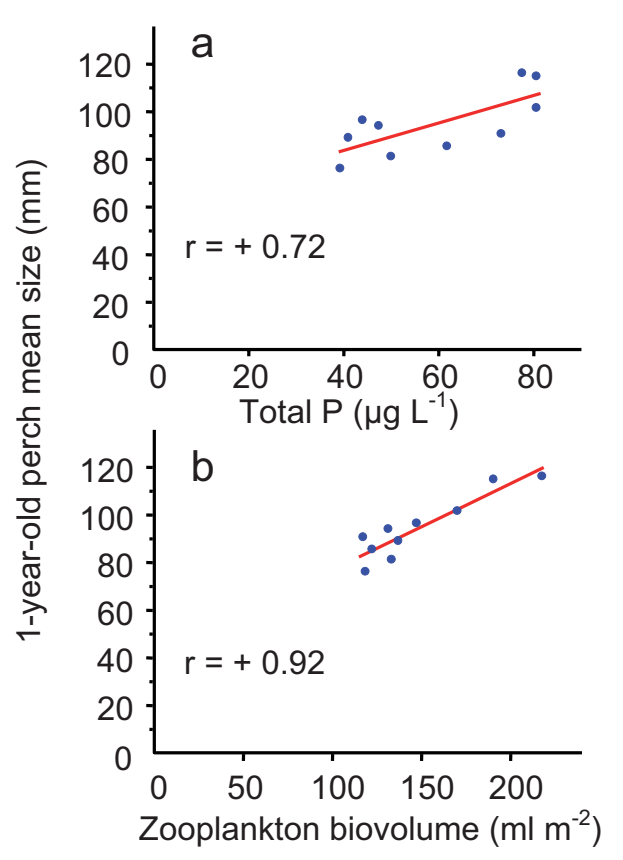

Fig. 6. (a) Correlations between total $P$ and mean size (TL mm) of one-year-old perch; and (b) between zooplankton biovolume and mean size of one-year-old perch. Data correspond to the strong cohorts only.

during the 16-year study period. In Lake Geneva, the predation exerted by strong cohorts on their offspring during the following 2 or 3 years may have greatly contributed to the cyclic fluctuations observed in perch abundance. Perch were not fished until they reached $150 \mathrm{~mm}$, the protective size limit, but then they were soon removed by fishermen (Lang 1987). Perch of strong cohorts dominated the perch population for several years, as reflected in the professional catches. Individuals born in 1988 constituted the majority of the perch caught in 1990, 1991 and 1992 (data of the Vaud county fisheries agency; Dubois, unpubl. data). The reduction of a strong cohort by fishing then allowed a new strong cohort to emerge. It is possible that cannibalistic pressure has increased during re-oligotrophication in Lake Geneva, as has been observed in Lake Constance because of the reduction of zooplankton and of submerged macrophytes that constitute natural shelters for young fish (Eckmann et al. 2006).

Climatic conditions can interfere with the settlement of strong cohorts. In Lake Geneva, during the period 19761981, unusually cold conditions during spring and summer (Anneville, pers. comm.) probably strongly reduced perch recruitment, resulting in low perch catches until 1982. Unfavourable climatic conditions are known to interfere with perch recruitment (Aalto and Newsome 1993). In Lake Neuchâtel (data from the cantonal Swiss fisheries agency) and Lake Constance (Eckmann et al. 2006), which are situated in the vicinity of Lake Geneva and therefore experienced the same climatic conditions, the same collapse of perch catches was observed from 1977 to 1981 . In all three lakes, the perch stock recovered after the warm spring of 1982. In 1992 and 1993, two consecutive large cohorts were born in Lake Geneva. Although cool temperatures in spring caused a partial reduction of the recruitment in 1992, warm spring temperatures in 1993 (Anneville, pers. comm.) enhanced recruitment in spite of the cannibalism and competition exerted by the preceding cohort.

\subsection{Effect of trophic changes on zooplankton biovolume; consequences for on perch yields}

Like many other alpine lakes (Gerdeaux et al. 2006; Eckmann et al. 2006), Lake Geneva has undergone two major trophic changes over the last 50 years. The concentration of $P$ increased 6-fold between the early 1960s and the early 1980s during the eutrophication process, and the biovolume of zooplankton increased markedly (Balvay 1998). As a result of the re-oligotrophication process, total $P$ returned to approximately $30 \mu \mathrm{g} \mathrm{L}^{-1}$ in the early 2000s. Throughout the period studied, zooplankton production was positively correlated with total $P$. The sharp decrease observed from 1981 to 1985, and detected by the DCPC analysis, was probably due to a combination of a decrease in total $P$ level and an increase in grazing pressure, because of the birth of a strong perch cohort in 1982 following a prolonged period of weak recruitment. Moreover, a strong roach cohort was also born in 1982 (Ponton pers. comm). Throughout the re-oligotrophication process, the continuous expansion of the whitefish population (Coregonus lavaretus) (Gerdeaux et al. 2006) probably contributed to controlling zooplankton populations. It is important to note that changes in the relative proportions of zooplankton species during the growing season have also occurred in Lake Geneva. For example, now that re-oligotrophication is occurring in Lake Geneva, calanids are increasing, while other copepods and herbivorous cladocerans are showing a decline (Anneville et al. 2007).

Lang and Lang (1983) found a close relationship between total $P$ and perch yields in the Swiss part of Lake Geneva, during the eutrophication period of 1964 to 1975 ( $r=0.69$; $n=12 ; p<0.05)$. An increase in perch yields has also been reported during eutrophication in Lake Constance (Eckmann et al. 2006), and in Lake Neuchâtel (data from the cantonal Swiss fisheries agency). Gerdeaux et al. (2006) described changes in fish catches in 11 peri-alpine lakes during eutrophication and re-oligotrophication. These studies revealed that the highest percid yields occurred when total $P$ levels were between 70 and $80 \mu \mathrm{g} \mathrm{L}^{-1}$ (eutrophic stage); above this level, and particularly with total $P>90 \mu \mathrm{g} \mathrm{L}^{-1}$, cyprinids became the dominant species, and percid yields decreased. The same pattern occurred in the hypertrophic shallow lakes of northern Europe (Jeppesen et al. 2000). Yearly mean perch yields during the re-oligotrophication period were only half those obtained before 1977, probably linked to a decrease in the food available for perch. This change in perch yields is found by the DCPC procedure in the period 1977-1981 when perch catches slumped; suggesting that the date calculated for the change is debatable. Yields vary considerably from year to year, and it is difficult to detect any relationship between the trophic status (total $P$ or zooplankton biovolume) and perch yields, such as the positive correlation proposed by Lang and Lang (1983). However, if only the three years of fishing associated with each of the successive strong cohorts are taken into account in calculating the correlation, then perch yields 
and zooplankton biovolume appear to be strongly correlated for the period 1963-2005. Calculations made over three-year periods can blur considerable differences in the values of the trophic parameters. It is possible to hypothesize that within strong cohorts intraspecific competition for food was more severe, and this meant that trophic changes had a marked effect on perch production and yield.

During the past 45 years, the number of fishermen and the level of fishing activity have not changed a great deal (Matthey 1975; Gerdeaux et al. 2006), so the relationships found between annual fish yields and trophic parameters in Lake Geneva (Lang and Lang 1983; this work) lead us to think that annual yields can be used as indicators of the stock of perch. Other observations also confirm this. In Lake Oneida between 1957 and 1974, Forney (1977) recorded parallel changes in the stock of mature females of walleye (Stizostedion vitreum vitreum), a percid fish evaluated by marking and recapture, and in the trap-net catches made during the breeding season. Additionally, Lang (1987) suggested that the abundance (density) of perch females could be reasonably accurately estimated from the abundance of egg-ribbons (see also Thorpe 1977), and in Lake Geneva, the density of eggribbons and annual perch yields were also positively correlated $(r=+0.70$; period 1984-1998) (Lang 1999).

\subsection{Effect of trophic and zooplankton changes on $0+$ perch growth}

The effect of total $P$ on $0+$ perch growth is not as direct as that on zooplankton, which could explain why correlations were always greater for zooplankton biovolume than for total $P$. The size of one-year-old perch was positively correlated with the trophic status, on average $16 \mathrm{~mm}$ greater during the period of highest trophic level than during the reoligotrophication period, slightly more than that observed in Lake Constance (1 cm; Eckmann et al. 2006). The $16 \mathrm{~mm}$ increase was equivalent to a 1.6 fold increase in weight (Dubois, unpub. data), which is comparable to the increase in the zooplankton biovolume estimated from the DCPC procedure.

Several authors have already described an improvement of perch growth in lakes undergoing eutrophication. Under oligotrophic conditions, the total $P$ is still an influential variable (O'Gorman and Burnett 2001), but has relatively little impact compared to competition for food and cannibalism (Sanderson et al. 1999). Zooplankton is the essential diet of $0+$ perch, and this has led to considerable qualitative and quantitative investigations (e.g., Mehner et al. 1998; Sanderson et al. 1999; Romare 2000). In Lake Constance, the abundance of zooplankton during eutrophication allowed even adult perch to feed mainly on such prey (Hartmann 1975); as a result of re-oligotrophication, food became limited and inter year-class competition increased (Eckmann et al. 2006).

The analysis of perch populations by cohorts provides useful information about the impact of the trophic level on $0+$ perch growth. Higher correlations were obtained for the strong cohorts than for all the cohorts combined, indicating that the strong cohorts were particularly sensitive to trophic status, and especially to the amount of zooplankton available. Under reoligotrophication conditions, strong cohorts had lower mean individual $0+$ growth than weak cohorts, as a result of competition for zooplankton. O'Gorman and Burnett (2001) observed that the growth of $0+$ perch was faster when age classes were small. Mehner et al. (1998) reported that the strength of year-classes was not related to the amount of zooplankton in Lake Bautzen, but that the size of the $0+$ fish at the end of the year was inversely related to the year-class strength. During eutrophication, zooplankton was abundant, and predation reduced, as observed by Hartmann (1975) and Lang and Lang (1983). As a result of re-oligotrophication, the zooplankton food source was less abundant, and this affected the growth of $0+$ perch, particularly in the strong cohorts.

As perch grow slowly once mesotrophic conditions have been restored, they take longer to reach exploitable size and attain maturity; and as a result the intervals between two successive strong cohorts increase. Moreover, with reoligotrophication, perch are subject to parasitism, as has been reported in Lake Constance (Brinker and Hamers 2007), and slower growing $0+$ perch are probably more vulnerable to predation (Eckmann et al. 2006). The combination of all these factors has probably contributed to the lowering of the perch yield in Lake Geneva.

\subsection{Interaction between climate warming and trophic changes in Lake Geneva}

In a context of climate warming, surface water temperature of Lake Geneva increased by approximately $1{ }^{\circ} \mathrm{C}$ during the study period, with a significant shift between 1987 and 1988 as has been observed in the western Alps (Beniston 2005). After 1988, the annual mean water temperature remained over $12{ }^{\circ} \mathrm{C}$ at a time when the trophic level was dropping continuously. It seems that the impact of the trophic level far exceeded that of the rising temperature on perch growth and perch yields. Moreover, the combination of temperature with zooplankton biovolume and/or total $P$ never greatly modified the value of correlation coefficients between perch yield and zooplankton, zooplankton and total $P$ or perch growth and zooplankton. In Lake Windermere, temperature has been shown to be a major factor in controlling perch growth or recruitment (Le Cren et al. 1977; Paxton et al. 2004). The lack of any measurable impact of temperature on perch growth or yield in Lake Geneva, and more generally in peri-alpine lakes (Massol et al. 2007), could be at least partly explained by the fact that this lake is warmer than Lake Windermere. In Lake Windermere, the sum of degree-days above $14{ }^{\circ} \mathrm{C}$ only exceeded 400 during warm summers, whereas in Lake Geneva, it was always above 400 degree-days (with a maximum 983 degree-days in 2003). However, surface water temperature of Lake Geneva never exceeded $24{ }^{\circ} \mathrm{C}$, the optimum for perch growth (Melard et al. 1996). The amount of available food is therefore probably more important than water temperature for the growth and yield of perch in Lake Geneva.

\section{Conclusion}

Perch growth and yields in Lake Geneva are related to total $P$, and especially dependent on the availability of 
zooplanktonic food, particularly in the case of strong cohorts. The influence of re-oligotrophication far outweighed the effects of rising temperature on perch growth and yields. If the total $P$ level continues to decline, perch performance could be more seriously affected.

Acknowledgements. This study is based in part on data collected by the CIPEL, by the French and Swiss fisheries administrations, and by the professional fishermen of Lake Geneva. We are grateful to Orlane Anneville, Claude Lang and Alexis Champigneulle for their helpful suggestions while we were writing this article.

\section{References}

Aalto S.K., Newsome G.E., 1993, Winds and the demic structure of a population of yellow perch, Perca flavescens. Can. J. Fish. Aquat. Sci. 50, 496-501.

Anneville O., Ginot V., Druart J.C., Angeli N., 2002, Long-term study (1974-1998) of seasonal changes in the phytoplankton in Lake Geneva: a multi-table approach. J. Plankton Res. 24, 993-1007.

Anneville O., Molinero J.C., Souissi S., Balvay G., Gerdeaux D., 2007, Long-term changes in the copepod community of Lake Geneva. J. Plankton Res. 29, 49-59.

Balvay G., 1998, Le zooplancton du Léman compartiment incontournable du réseau trophique. Arch. Sci. Genève 51, 45-54.

Beniston M., 2005, Mountain climates and climatic change: an overview of processes focusing on the European Alps Pure Appl. Geophys. 162, 1587-1606.

Brinker A., Hamers R., 2007, Evidence for negative impact of plerocercoid infection of Triaenophorus nodulosus on Perca fluviatilis L. stock in Upper Lake Constance, a water body undergoing rapid reoligotrophication. J. Fish Biol. 71, 129-147.

Champigneulle A., Gerdeaux D., 1995, Survey, management and recent rehabilitation of the Arctic char (Salvelinus alpinus) fishery in the French-Swiss Lake Leman. Nord. J. Freshw. Res. 71, 173182.

Craig J.F., Kipling C., Le Cren E.D., McCormack J.C., 1979, Estimates of the numbers, biomass and year-class strengths of perch (Perca fluviatilis L.) in Windermere from 1967 to 1977 and some comparisons with earlier years. J. Anim. Ecol. 48, 315-325.

Dubois J.P., Gillet C., Bonnet S., Chevalier-Weber Y., 1996, Correlation between the size of mature female perch (Perca fluviatilis L.) and the width of their egg strands in Lake Geneva. Ann. Zool. Fennici 33, 417-420.

Eckmann R., Gerster S., Kraemer A., 2006, Yields of European perch from Upper Lake Constance from 1910 to present. Fish. Manage. Ecol. 13, 381-390.

Forney J.L., 1977, Evidence of inter-and intra-specific competition as factors regulating walleye (Stizostedion vitreum vitreum) biomass in Oneida Lake, New-York. J. Fish. Res. Board Can. 34, 18121820.

Gerdeaux D., 2004, The recent restoration of the whitefish fisheries in Lake Geneva. Parts of the stocking, the reoligotrophication of the lake, climate change. Ann. Zool. Fennici 41, 181-189.

Gerdeaux D., Anneville O., Hefti D., 2006, Fishery changes during re-oligotrophication in 11 peri-alpine Swiss and French lakes over the past 30 years. Acta Oecol. 30, 161-167.

Gillet C., Dubois J.P., 1995, A survey of the spawning of perch (Perca fluviatilis), pike (Esox lucius), and roach (Rutilus rutilus), using artificial spawning substrates in lakes. Hydrobiologia 300/301, 409-415.
Gillet C., Dubois J.P., 2007, Effect of water temperature and size of females on the timing of spawning of perch Perca fluviatilis L. in Lake Geneva from 1984 to 2003. J. Fish Biol. 70, 1001-1014.

Gillet C., Dubois J.P., Bonnet, S., 1995, Influence of temperature and size of females on the timing of spawning of perch, Perca fluviatilis, in Lake Geneva from 1984 to 1993. Environ. Biol. Fishes $42,355-363$.

Hartmann J., 1975, Der Barsch (Perca fluviatilis) im eutrophierten Bodensee. (The perch (Perca fluviatilis) in the eutrophicated Lake of Constance). Arch. Hydrobiol. 76, 269-286.

Jeppesen E., Jensen P.J., Sondergaard M., Lauridsen T., Landkildehus F., 2000, Trophic structure, species richness and biodiversity in Danish lakes: changes along a phosphorus gradient. Freshw. Biol. 45, 201-218.

Lang B., Lang C., 1983, Effets combinés de la pêche et de l'eutrophisation sur la perche (Perca fluviatilis L.) dans les eaux vaudoises du Léman. Schweiz. Z. Hydrol. 45, 480-494.

Lang C., 1987, Mortality of perch Perca fluviatilis L., estimated from the size and abundance of egg-strands. J. Fish Biol. 31, 715-720.

Lang C., 1999, Abondance et taille des chaînes d'œufs et des femelles reproductrices dans la population de perche (Perca fluviatilis L.) du Léman. Bull. Soc. Vaud. Sci. Nat. 86, 175-184.

Lang C., Büttiker B., 1985, Abondance et survie des oeufs de perche dans le Léman et le lac de Joux. Bull. Soc. Vaud. Sci. Nat. 77, 285-295.

Lavielle M., 2005, Using penalized constrats for the change-point problem. Signal Processing 85, 1501-1510.

Le Cren E.D., 1947, The determination of the age and growth of the perch (Perca fluviatilis) from the opercular bone. J. Anim. Ecol. 16, 188-204.

Le Cren E.D., 1958, Observations on the growth of perch (Perca fluviatilis $\mathrm{L}$.) over twenty-two years with special reference to the effects of temperature and changes in population density. J. Anim. Ecol. 27, 287-334.

Le Cren E.D., Kipling C., McCormack J.C., 1977, A study of the numbers, biomass and year-class strengths of perch (Perca fluviatilis L.) in Windermere from 1941 to 1966. J. Anim. Ecol. 46, 281-307.

Massol F., David P., Gerdeaux D., Jarne P., 2007, The influence of trophic status and large-scale climatic change on the structure of fish communities in Perialpine lakes. J. Anim. Ecol. 76, 538-551.

Matthey G., 1975, La pêche dans les eaux vaudoises du lac Léman. Schweiz. Z. Hydrol. 37, 200-212.

Mehner T., Dorner H., Schultz H., 1998, Factors determining the year-class strength of age-0 Eurasian perch (Perca fluviatilis L.) in a biomanipulated reservoir. Arch. Fish. Mar. Res. 46, 241-251.

Mélard C., Kestemont P., Grignard J.C., 1996, Intensive culture of juvenile and adult Eurasian perch (Perca fluviatilis): Effect of major biotic and abiotic factors on growth. J. Appl. Ichthyol. 12, 175180.

Molinero J.C., Anneville O., Souissi S., Balvay G., Gerdeaux D., 2006, Anthropogenic and climate forcing on the long-term changes of planktonic rotifers in Lake Geneva, Europe. J. Plankton Res. 28, 287-296.

Nepzy S.J., 1977, Changes in percid populations and species interactions in Lake Erie. J. Fish. Res. Board Can. 34, 1861-1868.

O'Gorman R., Burnett J.A.D., 2001, Fish community dynamics in northeastern Lake Ontario with emphasis on the growth and reproductive success of yellow perch (Perca flavescens) and white perch (Morone americana), 1978 to 1997. J. Great Lakes Res. 27, 367-383.

Paxton C.G.M., Winfield I.J., Fletcher J.M., George D.G., Hewitt D.P., 2004, Biotic and abiotic influences on the recruitment of 
perch (Perca fluviatilis) in Windermere, U.K.J. Fish Biol. 65, 1622-1642.

Persson L., Byström P., Wahlström E., 2000, Cannibalism and competition in Eurasian perch: population dynamics of an ontogenetic omnivore. Ecology 81, 1058-1071.

Picard F., Robin S., Lavielle M., Vaisse C., Daudin J.J., 2005, A statistical approach for array $\mathrm{CGH}$ data analysis. BMC Bioinformatics $6,1-14$.

Romare P., 2000, Growth of larval and juvenile perch: the importance of diet and fish density. J. Fish Biol. 56, 876-889.

Rundberg, H. 1977, Trends in harvest of pikeperch (Stizostedion lucioperca), Eurasian perch (Perca fluviatilis), and northern pike
(Esox lucius) and associated environmental changes in lakes Mälaren and Hjälmaren, 1914-74. J. Fish. Res. Board Can. 34, 1720-1724.

Sanderson B.L., Hrabik T.R., Magnuson J.J., Post D.M., 1999, Cyclic dynamics of a yellow perch (Perca flavescens) population in an oligotrophic lake: evidence for the role of intraspecific interactions. Can. J. Fish. Aquat. Sci. 56, 1534-1542.

Thorpe J.E., 1977, Synopsis of biological data on the perch Perca fluviatilis Linnaeus, 1758 and Perca flavescens Mitchill, 1874. FAO (Food and Agriculture Organization of the United Nations) Fisheries Synopsis 113. 